\title{
Boosting efficiency of planar heterojunction perovskite solar cells by a low temperature $\mathrm{TiCl}_{4}$ treatment
}

\author{
Enqi Wang*, Peng Chen*, Xingtian Yin*, Bowen $\mathrm{Gao}^{\dagger}$ and Wenxiu Que** \\ *Electronic Materials Research Laboratory \\ Key Laboratory of the Ministry of Education \\ International Center for Dielectric Research \\ Shaanxi Engineering Research Center of Advanced Energy Materials and Devices \\ School of Electronic \& Information Engineering \\ $X i$ 'an Jiaotong University \\ Xi'an 710049, Shanxi, P. R. China \\ ${ }^{\dagger}$ School of Machinery and Architectural Engineering \\ Taishan University, Taian 271021, P. R. China \\ twxque@mail.xjtu.edu.cn
}

Received 23 January 2018; Revised 11 March 2018; Accepted 12 March 2018; Published 17 April 2018

\begin{abstract}
It is well known that electron transport layer (ETL) plays an indispensable role in the planar heterojunction perovskite solar cells (PSCs). $\mathrm{TiO}_{2}$ is widely used as an ETL material due to its excellent transport properties, however, the presence of defects in the $\mathrm{TiO}_{2}$ layer diminishes the power conversion efficiency (PCE) of the devices. Herein, we introduce a method of low-temperature $\mathrm{TiCl}_{4}$ treatment to deposit a $\mathrm{TiO}_{x}$ layer on the surface of $\mathrm{TiO}_{2}$ film, which can effectively passivate trap states at the $\mathrm{TiO}_{2}$ surface. Moreover, the treating process is optimized to be $30 \mathrm{~min}$ using a $40 \mathrm{mM} \mathrm{TiCl} \mathrm{T}_{4}$ aqueous solution. Benefiting from this, we obtain the champion device with the highest PCE of $18.47 \%$, which is mainly due to the reduction of surface defects and the deposition of the well-crystallized perovskite films. Besides, the modified PSCs exhibit an average PCE of $17.59 \%$, which is much better than the control devices.
\end{abstract}

Keywords: Perovskite solar cells; $\mathrm{TiO}_{2} ; \mathrm{TiCl}_{4}$; surface modification.

\section{Introduction}

Over the past years, the organic-inorganic hybrid perovskite solar cells (PSCs) have attracted particular attention owing to their excellent charge transport properties, ${ }^{1}$ large absorption coefficient ${ }^{2}$ and broad absorption band. ${ }^{3}$ Benefit from these excellent properties, the power conversion efficiency of PSCs has rapidly increased from $3.8 \%$ in $2009^{4}$ to $22.7 \%$ in $2017 .^{5}$ At present, the two main structures in the field of perovskite solar cells are mesoscopic structure ${ }^{6}$ and planar heterojunction structure. ${ }^{7}$ The most prominent characteristic of the mesoscopic structure is the introduction of nanoparticles as a mesoporous scaffold, so that the perovskite precursor solution filled inside the scaffold adequately to obtain a continuous and uniform perovskite film. At the same time, due to the simple device structure and fabrication process, the planar heterojunctions PSCs have achieved rapid development as well. In this structure, the perovskite active layer is sandwiched between charge selective transport layers ${ }^{8,9}$ without the mesoporous scaffold, thereby making the PSCs preparation more simplified and reducing the constraint of the device preparation conditions.
In the planar heterojunction structure, the electron transport layer (ETL) between the active perovskite material and the cathode plays a significant role in hole blocking and electron extraction. Currently, the materials used for the ETL includes organic materials and inorganic materials such as $\mathrm{TiO}_{2},{ }^{10} \mathrm{ZnO},{ }^{11,12} \mathrm{SnO}_{2}{ }^{13}$ and phenyl-C61-butyric acid methyl ester (PCBM), etc. ${ }^{14}$ Among them, $\mathrm{TiO}_{2}$ is the most widely used ETL material, mainly owing to its chemical stability, ${ }^{15}$ electronic and optical properties ${ }^{16}$ and compatibility with various deposition methods. ${ }^{17}$ Nevertheless, there are numerous trap states in the surface of $\mathrm{TiO}_{2}$ films, leading to ineffective charge transportation and severe charge recombination. ${ }^{18}$ As an effective method to modify the surface of $\mathrm{TiO}_{2}$ films, chemical bath deposited $\mathrm{TiO}_{x}$ films have been proposed by some researchers to improve the performance of the PSCs. For example, Yella et al. introduced a low-temperature route for the fabrication of $\mathrm{TiO}_{2} / \mathrm{CH}_{3} \mathrm{NH}_{3} \mathrm{PbI}_{3}$ solar cells using $\mathrm{TiCl}_{4}$ chemical bath deposition technique and thus achieved better performance. ${ }^{19}$ In addition, Liu et al. confirmed $\mathrm{TiCl}_{4}$ treatment improved the contact of the $\mathrm{TiO}_{2} /$ perovskite interface, facilitating charge extraction and

This is an Open Access article published by World Scientific Publishing Company. It is distributed under the terms of the Creative Commons Attribution 4.0 (CC-BY) License. Further distribution of this work is permitted, provided the original work is properly cited. 
suppressing charge recombination. ${ }^{20}$ Similarly, Murakami et al. also studied the mechanism of $\mathrm{TiCl}_{4}$ treatment and demonstrated that through the $\mathrm{TiCl}_{4}$ treatment, the conduction band edge of the compact $\mathrm{TiO}_{2}$ layer was shifted to a higher level and the performance of PSC was improved. ${ }^{21}$ However, the relationship between the performance of device and the $\mathrm{TiCl}_{4}$ treating time remains unclear.

Herein, we employed a facile $\mathrm{TiCl}_{4}$ treatment method with certain concentration to improve the surface properties of $\mathrm{TiO}_{2}$ and systematically studied the effect of treating time on the performance of the devices. We optimized the treatment time as $30 \mathrm{~min}$ and obtained a more uniform and less pinhole ETL after treatment. As a result, the devices based on the structure of $\mathrm{FTO} / \mathrm{TiO}_{x}$ /perovskite (PVSK)/spiro-OMeTAD/ $\mathrm{Ag}$ showed dramatic improvement of $\mathrm{FF}$ and $J_{\mathrm{SC}}$, leading to the champion efficiency of $18.47 \%$ with an average value of $17.59 \%$, which was much better than the control devices.

\section{Experimental Section}

\subsection{Materials and chemicals}

Li-bis-(trifluoromethanesulfonyl) imide (Li-TFSI), 4-tertbutylpyridine (TBP), dimethylsulphoxide (DMSO), chlorobenzene (CB) and $\mathrm{N}, \mathrm{N}$-dimethylformamide (DMF) were supplied by Alfa-Aesar. $\mathrm{CH}_{3} \mathrm{NH}_{3} \mathrm{I}$ (MAI, 95\%), lead iodide (PbI2, 99.9\%) and 2,2',7,7'-tetrakis (N, N-di-p-methoxyphenylamine)-9,90-spirobifluorene (spiro-OMeTAD, 99.5\%) were purchased from Xi'an p-OLED. Other reagents including $\mathrm{TiCl}_{4}$ (Chemically Pure) were received from Sinopharm Chemical Reagent.

\subsection{Substrate Preparation and surface treatment}

FTO-coated glass sheets were patterned by a selective etching with diluted $\mathrm{HCl}$ aqueous solution and $\mathrm{Zn}$ powders, then cleaned sequentially by ultrasonication in Hellmanex detergent diluted in deionized (DI) water, DI water, acetone and ethanol for $15 \mathrm{~min}$ each. After that, a UV-ozone treatment was performed for $15 \mathrm{~min}$.

\subsection{Solar cell fabrication}

The compact $\mathrm{TiO}_{2}$ layer was obtained by spin-coating a solution prepared by mixing $10 \mathrm{ml}$ of ethanol, $109 \mathrm{mg}$ of diethanolamine and $471 \mathrm{mg}$ of tetrabutyl titanate at $500 \mathrm{rpm}$ for $6 \mathrm{~s}$ and $3000 \mathrm{rpm}$ for $30 \mathrm{~s}^{22}$ Then, the film was annealed at $500^{\circ} \mathrm{C}$ for $30 \mathrm{~min}$. After cooling to room temperature, the substrates were treated by a UV-Ozone for $15 \mathrm{~min}$ again. The substrates with $\mathrm{TiO}_{2}$ films were then immersed in $40 \mathrm{mM}$ aqueous $\mathrm{TiCl}_{4}$ solution at $70^{\circ} \mathrm{C}$ for various time. Following, the samples cleaned by ethanol and dried with clean $\mathrm{N}_{2}$. And then all the samples were annealed at $130^{\circ} \mathrm{C}$ for $30 \mathrm{~min}$ together. After that, the perovskite solution was deposited in a one-step process by spin-coating at $1000 \mathrm{rpm}$ for $5 \mathrm{~s}$ and then at $3000 \mathrm{rpm}$ for $30 \mathrm{~s}$. During the second spin-coating step, $130 \mu \mathrm{l} \mathrm{CB}$ was dropwise added onto the wet film. Here, the perovskite precursor solution was prepared by dissolving of $1 \mathrm{mmol} \mathrm{PbI}_{2}$ and $1 \mathrm{mmol} \mathrm{CH}_{3} \mathrm{CH}_{3} \mathrm{I}$ with different molar ratios in $1 \mathrm{ml}$ mixed solvents of DMSO: DMF $=3: 7$. The mixture was stirred at $70^{\circ} \mathrm{C}$ for more than $6 \mathrm{~h}$ and filtered through a PTFE filter $(0.45 \mu \mathrm{m})$ before use. Thereafter, the perovskite film was annealed at $70^{\circ} \mathrm{C}$ for $4 \mathrm{~min}$ and then annealed at $100^{\circ} \mathrm{C}$ for $20 \mathrm{~min}$. Then a hole-transport layer precursor solution was prepared by dissolved Spiro-OMeTAD $(72.3 \mathrm{mg})$, 4-tert-butylpyridine $(28.8 \mu \mathrm{l})$ and Li-TFSI/acetonitrile (17.5 $\mu \mathrm{l}$, Aldrich) in CB (1 ml). The final solution was stirred for one night and then spin-coated onto the perovskite films as the hole-transporting layer at a speed of $2000 \mathrm{rpm}$ for $30 \mathrm{~s}$. Finally, the monolithic device fabrication was completed by evaporating the Ag back electrode.

\subsection{Characterization}

The crystallinity of the samples was characterized by X-ray diffraction (XRD, D/max $2400 \mathrm{X}$ Series, Rigaku, Japan). Energy dispersive spectrum (EDS) mapping of the $30 \mathrm{~min}$ $\mathrm{TiCl}_{4}$ treatment on the $\mathrm{TiO}_{2}$ films were observed using a field emission SEM (FE-SEM, Quanta F250, JEOL Inc., Japan). The absorption and transmittance spectra of the films were tested by a JASCOV-570 UV/VIS/NIR spectrometer. The current density-voltage $(\mathrm{J}-\mathrm{V})$ characteristics under AM 1.5G simulated solar illumination were measured using a PVIV201V I-V Station (Newport Oriel), and the prepared devices were reversely scanned $(1.2 \mathrm{~V} \rightarrow-0.1 \mathrm{~V}, 66$ data points) with a $100 \mathrm{~ms}$ time interval.

\section{Results and Discussion}

To elucidate the changes of morphologies after $\mathrm{TiCl}_{4}$ treatment, we treated the $\mathrm{FTO} / \mathrm{TiO}_{2}$ substrates with a certain concentration of $\mathrm{TiCl}_{4}$ aqueous solution with different times to deposit a $\mathrm{TiO}_{x}$ layer. For the sake of simplicity, the samples will be labeled $\mathrm{TiCl}_{x}$, where $x$ denotes the $\mathrm{TiCl}_{4}$ treating time, e.g., $\mathrm{TiCl} 30$ corresponds to a $\mathrm{FTO} / \mathrm{TiO}_{2}$ sample with $30 \mathrm{~min}$ $\mathrm{TiCl}_{4}$ treatment. Firstly, the samples were carried out with SEM characterization as shown in Fig. 1. In Fig. 1(a), it can be seen that there are some cracks on the surface of the untreated films, which may be attributed to the incomplete coverage of the substrates with $\mathrm{TiO}_{2}$ films fabricated at high temperature. The presence of these surface cracks may lead to direct contact of the perovskite films with the substrates, thereby decreasing the PCE of devices. As shown in Figs. 1(b)-1(d), after the $\mathrm{TiCl}_{4}$ treatment, a large proportion of cracks are eliminated. The improvements of these surface morphologies are due to fact that the post-treatment deposited $\mathrm{TiO}_{x}$ on the surface of $\mathrm{TiO}_{2}$ fills these cracks and makes the surface smoother. Therefore, it is found that the $\mathrm{TiCl}_{4}$ treatment did improve the morphology of $\mathrm{TiO}_{2}$ films. To explore the elemental distribution of $\mathrm{TiCl}_{4}$-treated films, we 

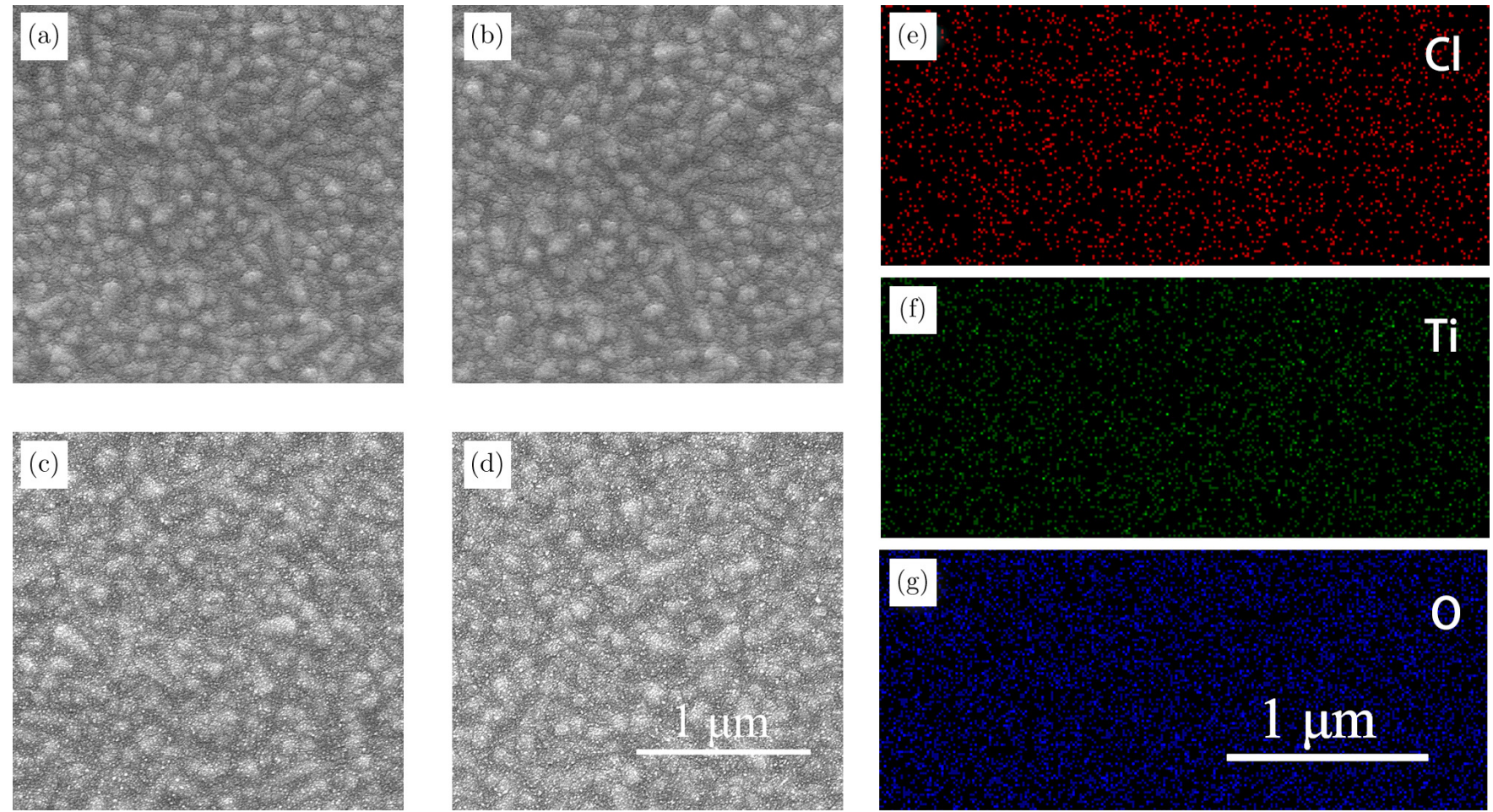

Fig. 1. Top-view SEM images of $\mathrm{FTO} / \mathrm{TiO}_{2}$ substrates with different $\mathrm{TiCl}_{4}$ treating time: (a) TiCl0, (b) $\mathrm{TiCl15}$, (c) $\mathrm{TiCl} 30$ and (d) $\mathrm{TiCl} 60$. EDS images (e) $\mathrm{Cl}$ element, (f) Ti element and (g) $\mathrm{O}$ element mapping showing the effect on 30 min $\mathrm{TiCl}_{4}$ treatment of FTO substrates.

conducted EDS mapping measurement. Figures $1(\mathrm{e})-1(\mathrm{~g})$ shows the $\mathrm{Cl}$ element, $\mathrm{Ti}$ element and $\mathrm{O}$ element, respectively. It can be seen that although the thermal treatment at $130^{\circ} \mathrm{C}$ has been carried out after $\mathrm{TiCl}_{4}$ treatment, $\mathrm{Cl}$ elements still preserved, and these three elements are uniformly distributed on the surface of the films. Other researchers demonstrated that $\mathrm{Cl}$ ions affect the growth of the $\mathrm{CH}_{3} \mathrm{NH}_{3} \mathrm{PbI}_{3}$ and the presence of $\mathrm{Cl}$ ions source in the starting solutions used for the perovskite deposition resulted in a strong increase of the overall charge diffusion length. ${ }^{23,24}$ Therefore, it can be speculated that the presence of the $\mathrm{Cl}$ ions on the surface of the films can improve the device performance.

To gain insight into the influence of $\mathrm{TiCl}_{4}$ treatment on the optical properties of $\mathrm{TiO}_{2}$, we performed a transmittance measurement. As depicted in Fig. 2, after treated with $\mathrm{TiCl}_{4}$, the transmittances of $\mathrm{TiO}_{2}$ substrates were slightly lower than the control sample. Moreover, there is no significant difference in the transmittances of $\mathrm{TiO}_{2}$ substrates as for different treating time, indicating that the treating time has little effect on the transmittances over a wide time range.

The quality of perovskite films directly affects the device performance of PSCs. Therefore, to investigate the effect of post-treatment of $\mathrm{TiO}_{2}$ on the deposition of the perovskite film, we deposited perovskite thin films on top of the $\mathrm{TiO}_{2}$ films with $30 \mathrm{~min} \mathrm{TiCl}_{4}$ treatment. The analysis of absorption spectra, XRD and SEM have been investigated. Figure 3(a) shows the spectra of absorption for the planar heterojunction PSCs with and without $\mathrm{TiCl}_{4}$ treatment. It can be found that

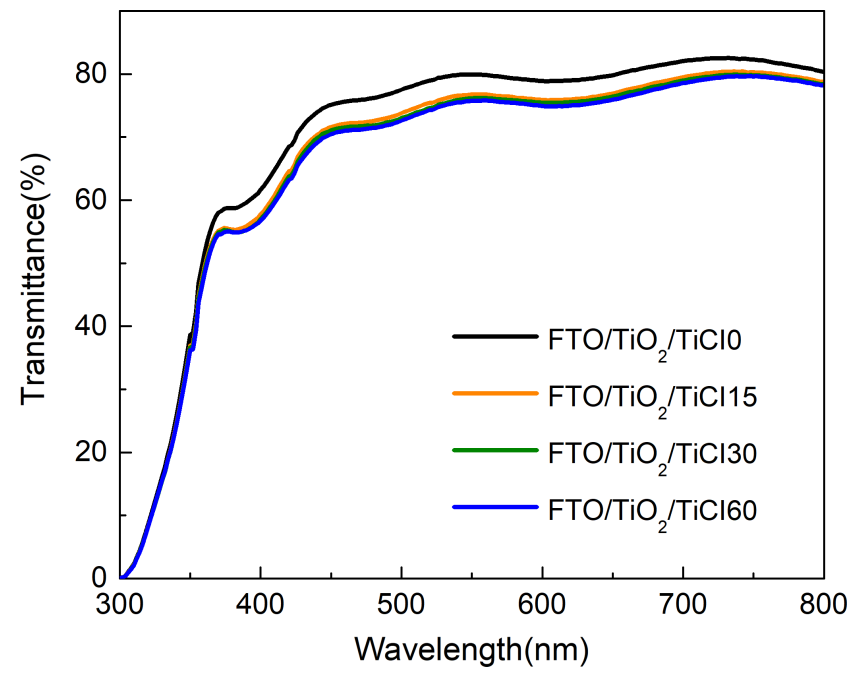

Fig. 2. Transmission spectra of $\mathrm{TiO}_{x}$ deposited on $\mathrm{TiO}_{2}$-coated FTO with different $\mathrm{TiCl}_{4}$ treating time $(0,15,30$ and 60$)$.

the absorbance was enhanced for perovskite films on $30 \mathrm{~min}$ $\mathrm{TiCl}_{4}$ treated $\mathrm{TiO}_{2}$ as compared with the control samples. To study the effect of $\mathrm{TiCl}_{4}$ treatment on the crystallization of perovskites, XRD characterization was performed as shown in Fig. 3(b). The two curves show the same characteristic peaks at $14.2^{\circ}, 28.5^{\circ}$ and $31.8^{\circ}$, which are indexed to the (110), (220) and (310) planes of the $\mathrm{CH}_{3} \mathrm{NH}_{3} \mathrm{PbI}_{3}$. Meanwhile, the XRD patterns show that the crystallinity of the 


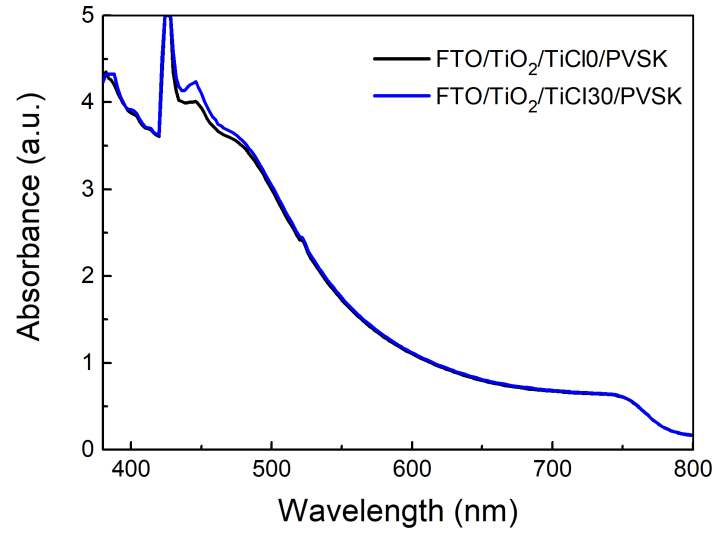

(a)

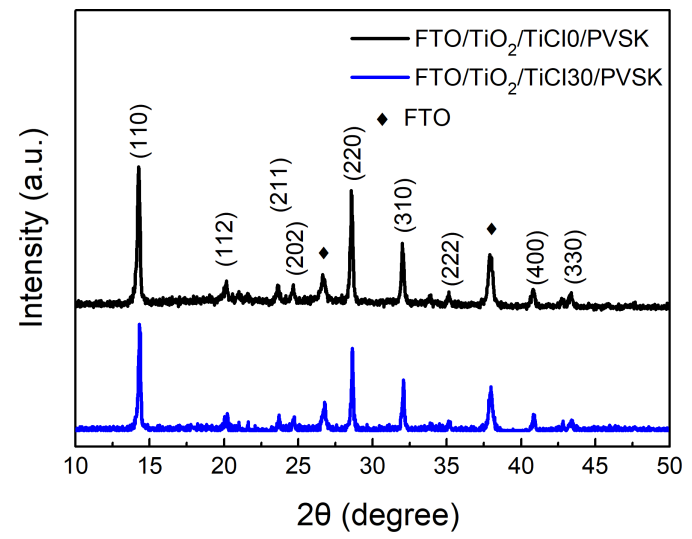

(b)

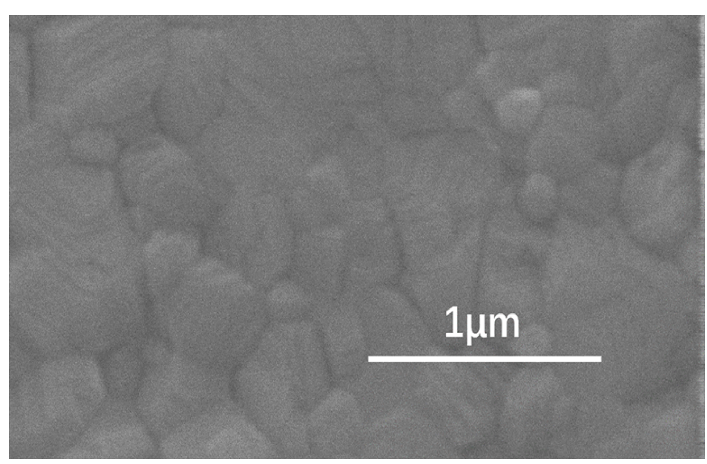

(c)

Fig. 3. (a) Absorption spectra of perovskite films deposited on the $\mathrm{TiO}_{2}$ films with $30 \mathrm{~min}$ or without $\mathrm{TiCl}_{4}$ treatment. (b) XRD patterns of perovskite films on the $\mathrm{TiO}_{2}$ films with 30 min or without $\mathrm{TiCl}_{4}$ treatment. (c) Top-view $\mathrm{SEM}$ images of perovskite films on $\mathrm{TiO}$ films.

perovskite films is not affected by the post-treatment. Then, we further observed the morphology of the perovskite films deposited on $\mathrm{TiCl}_{4}$-treated $\mathrm{TiO}_{2}$ surface by SEM as shown in Fig. 3(c). It is found that perovskite films exhibit smooth, uniform and large crystal grains on the $\mathrm{TiO}_{x}$ films.

Based the above studies, it can be found that $\mathrm{TiCl}_{4}$ treatment can improve the surface morphology of $\mathrm{TiO}_{2}$ films and has an insignificant effect on the crystallinity of the perovskite films. To further determine the optimal treating time, we have assembled the resulting planar heterojunction PSCs. These devices employ $\mathrm{TiO}_{2}$ and Spiro-OMeTAD as the charge extraction layer, with the active layer of perovskite sandwiched between them and an $\mathrm{Ag}$ electrode as the back electrode. Unlike other devices using $\mathrm{TiO}_{2}$ as ETL, we deposited a $\mathrm{TiO}_{x}$ film by $\mathrm{TiCl}_{4}$ treatment of different time on the surface of $\mathrm{TiO}_{2}$ before the perovskite deposition as shown schematically in Fig. 4(a). In addition, the cross-sectional SEM based on the $\mathrm{TiO}_{x} / \mathrm{TiO}_{2}$ ETL is shown in Fig. 4(b).

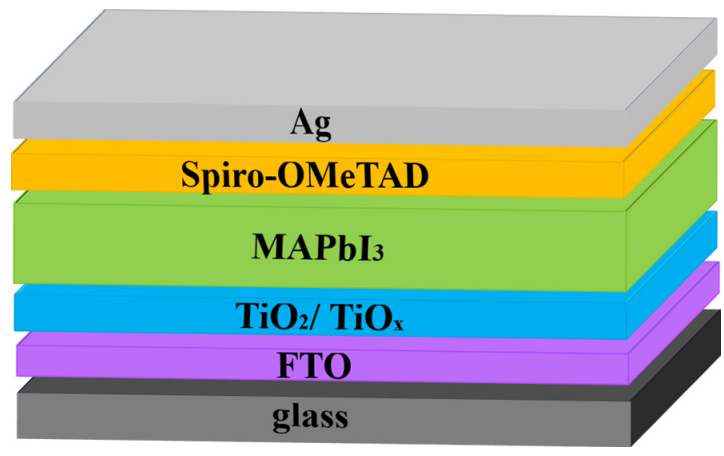

(a)

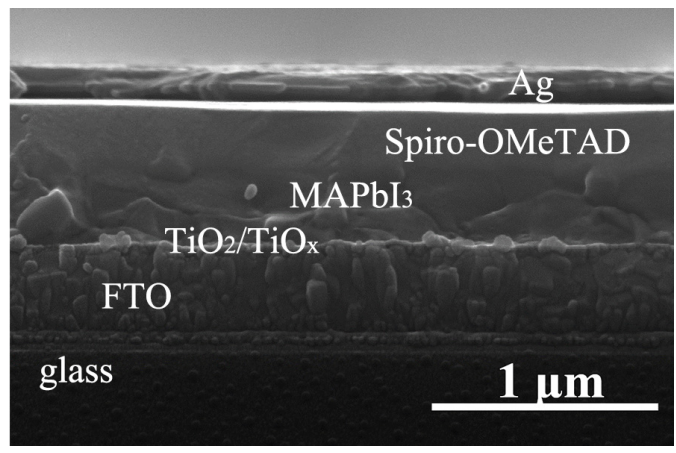

(b)

Fig. 4. (a) Schematic illustration of the device structure. (b) The cross-sectional SEM micrograph of typical PSC devices. 


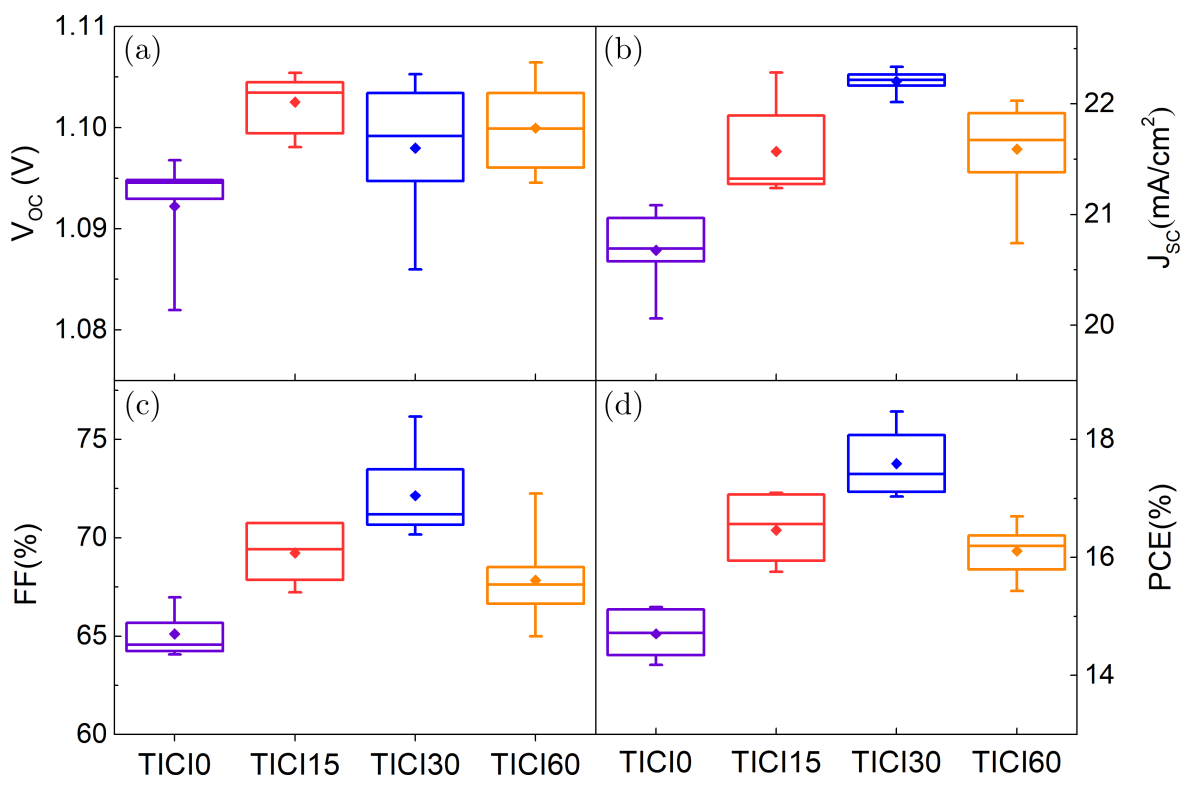

Fig. 5. The box-chart images of (a) open-circuit voltage $\left(V_{\mathrm{OC}}\right)$, (b) short-circuit current density $\left(J_{\mathrm{SC}}\right)$, (c) fill factor (FF) and (d) power conversion efficiency (PCE) for devices with different $\mathrm{TiCl}_{4}$ treating time $(0,15,30$ and 60$)$ which extracted from measuring current densityvoltage curves at simulated one sun illumination.

The values of the device parameters, such as open-circuit voltage $\left(V_{\mathrm{OC}}\right)$, short-circuits current density $\left(J_{\mathrm{SC}}\right)$, fill factor (FF) and PCE are shown in Fig. 5 with box-charts. These photovoltaic properties were evaluated under standard simulated sunlight (AM 1.5G) irradiation at a reverse scan. The mean values and standard deviations of the photovoltaic performance parameters are listed and compared in Table 1. It can be found that, as the time of the $\mathrm{TiCl}_{4}$ treatment increases from 0 to $30 \mathrm{~min}$, the $V_{\mathrm{OC}}$ remains nearly constant around $1.10 \mathrm{~V}$ and the average $J_{\mathrm{SC}}$ increases from 20.68 to $22.20 \mathrm{~mA} / \mathrm{cm}^{2}$. This enhancement of $J_{\mathrm{SC}}$ is consistent with an increase of absorption shown after the surface treatment of the perovskite films in Fig. 3(a). As reported before, several mechanisms should be accounted for the increase of $J_{\mathrm{SC}}$. Firstly, a shift in the conduction band edge of the $\mathrm{TiO}_{2}$ after $\mathrm{TiCl}_{4}$ treatment improves the capacity of charge injection into the $\mathrm{TiO}_{2}{ }^{25}$ Secondly, the $\mathrm{TiCl}_{4}$ post-treatment passivates the defect sites of $\mathrm{TiO}_{2}$ and reduces the rate of recombination. ${ }^{26}$ Thirdly, the $\mathrm{TiCl}_{4}$ treatment enhances transport in the active layer, which supports lower recombination and enhances charge collection at the adjacent contact. ${ }^{27}$ Moreover, the average fill factor (FF) obtained with three different treatment

Table 1. Average photovoltaic parameters for PSCs devices extracted from J-V curves in Fig. 5.

\begin{tabular}{lcccc}
\hline Samples & $V_{\mathrm{OC}}(\mathrm{V})$ & $J_{\mathrm{SC}}\left(\mathrm{mA} / \mathrm{cm}^{2}\right)$ & FF $(\%)$ & PCE $(\%)$ \\
\hline TiCl0 & $1.09 \pm 0.006$ & $20.68 \pm 0.4$ & $65.11 \pm 1.2$ & $14.70 \pm 0.4$ \\
TiCl15 & $1.10 \pm 0.003$ & $21.57 \pm 0.4$ & $69.22 \pm 1.3$ & $16.46 \pm 0.5$ \\
TiCl30 & $1.10 \pm 0.007$ & $22.20 \pm 0.1$ & $72.14 \pm 2.3$ & $17.59 \pm 0.6$ \\
TiCl60 & $1.09 \pm 0.004$ & $21.59 \pm 0.4$ & $67.85 \pm 2.1$ & $16.11 \pm 0.4$ \\
\hline
\end{tabular}

(TiCl0, TiCl15, TiCl30) are $65.11 \pm 1.2 \%, 69.22 \pm 1.3 \%$ and $72.14 \pm 2.3 \%$, respectively. In general, smaller series resistance $\left(R_{S}\right)$ and larger shunt resistance $\left(R_{\mathrm{sh}}\right)$ will get larger FF. Here, the increase in FF is mainly due to better contact between perovskite film and $\mathrm{TiO}_{2}$ film, higher perovskite film coverage, and better hole-blocking abilities after $\mathrm{TiCl}_{4}$ treatment, which resulting in the decreasing of $R_{s}$ and the increasing of $R_{\mathrm{sh}} \cdot{ }^{20,28}$ The average PCE of devices without treatment is $14.70 \pm 0.4 \%$ and increase to $16.46 \pm 0.5 \%$ and $17.59 \pm 0.6 \%$ after surface treatment of the $\mathrm{TiCl}_{4}$ for 15 and $30 \mathrm{~min}$. This further confirms that the performance of $\mathrm{TiCl}_{4}$ treated cells is much better than that of control devices with a

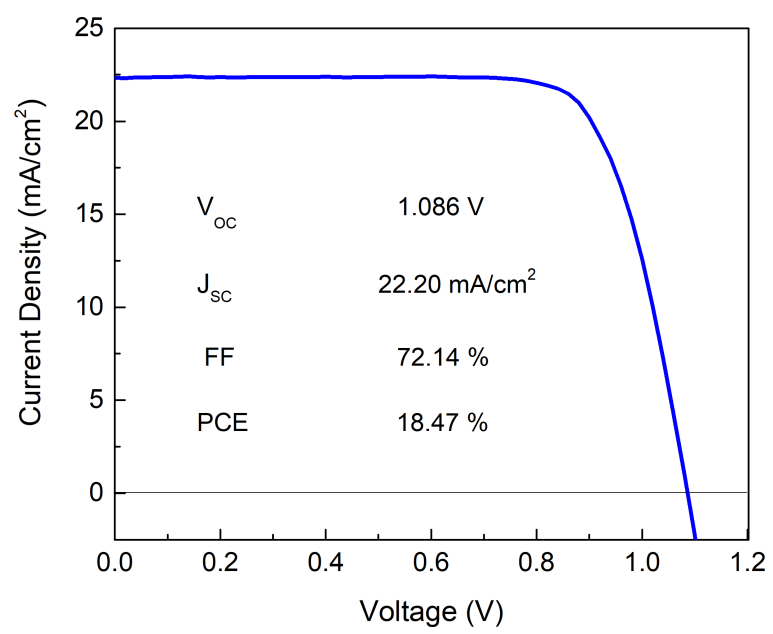

Fig. 6. The $\mathrm{J}-\mathrm{V}$ curves and photovoltaic parameters measured from the devices with the structure of $\mathrm{FTO} / \mathrm{TiO}_{2} / \mathrm{TiCl} 30 / \mathrm{PVSK} /$ spiroOMeTAD/Ag. 
bare $\mathrm{TiO}_{2}$ ETL. However, when we continued to increase the treating time, the $J_{\mathrm{SC}}, \mathrm{FF}$ and PCE decreased to $21.59 \pm 0.4 \mathrm{~mA} / \mathrm{cm}^{2}, 67.85 \pm 2.1 \%$ and $16.11 \pm 0.4 \%$, respectively. It is likely to be attributed to that, as the treating time increases, the thickness of $\mathrm{TiO}_{x}$ films and resistance increase, which results in the decrease of PCE. Therefore, we optimized the treating time to be $30 \mathrm{~min}$. In the end, we showed the $\mathrm{J}-\mathrm{V}$ curves and photovoltaic parameters of the optimal PSCs based on $30 \mathrm{~min} \mathrm{TiCl}_{4}$ treatment in Fig. 6. Benefit from the modification of the surface of ETL with the optimal treating time, the champion PCE of $18.47 \%$ is achieved, with $V_{\mathrm{OC}}, J_{\mathrm{SC}}$, and FF of $1.086 \mathrm{~V}, 2.20 \mathrm{~mA} / \mathrm{cm}^{2}$ and $72.14 \%$, respectively. This series of values indicate that $\mathrm{TiCl}_{4}$ treatment is an effective method to improve the performance of device.

\section{Conclusion}

In summary, we employed a surface modification method of low-temperature $\mathrm{TiCl}_{4}$ treatment, depositing a $\mathrm{TiO}_{x}$ layer on the surface of $\mathrm{TiO}_{2}$ films for planar heterojunction perovskite solar cells (PSCs). The treatment was optimized to be $30 \mathrm{~min}$ using a $40 \mathrm{mM} \mathrm{TiCl}_{4}$ aqueous solution. We found that the insertion of $\mathrm{TiO}_{x}$ can significantly reduce the defects and effectively improve the smoothness of $\mathrm{TiO}_{2}$ surface. As a result, the devices with the structure of $\mathrm{FTO} / \mathrm{TiO}_{2} / \mathrm{TiO}_{x} /$ PVSK/spiro-OMeTAD/Ag showed a dramatic enhanced average PCE from $14.70 \%$ to $17.59 \%$ with the maximum PCE of $18.47 \%$. Our research results demonstrate that the surface modification method of low-temperature $\mathrm{TiCl}_{4}$ treatment with appropriate treating time could be an effective way to obtain highly efficient PSCs.

\section{Acknowledgments}

This work was funded by China Postdoctoral Science Foundation under Grant No. 2017T100751, Natural Science Foundation of Shandong Province under Grant No. ZR2017MF007, Shandong Science and Technology Plan Project of Higher Education Institutions under Grant No. J16LA02 and the 111 Project of China (B14040). The SEM work was done at International Center for Dielectric Research, Xi'an Jiaotong University, Xi'an, P. R. China.

\section{References}

${ }^{1}$ C. S. Ponseca, T. J. Savenije, M. Abdellah, K. B. Zheng, A. Yartsev, T. Pascher, T. Harlang, P. Chabera, T. Pullerits, A. Stepanov, J. P. Wolf and V. Sundstrom, Organometal halide perovskite solar cell materials rationalized: Ultrafast charge generation, high and microsecond-long balanced mobilities, and slow recombination, J. Am. Chem. Soc. 136, 5189 (2014).

${ }^{2}$ C. Wehrenfennig, G. E. Eperon, M. B. Johnston, H. J. Snaith and L. M. Herz, High charge carrier mobilities and lifetimes in organolead trihalide perovskites, Adv. Mater. 26, 1584 (2014).
${ }^{3}$ N. M. Guichuan Xing, S. Sun, S. S. Lim, Y. M. Lam, M. Grätzel, S. Mhaisalkar and T. Chien Sum1, Long-range balanced electronand hole-transport lengths in organic-inorganic $\mathrm{CH}_{3} \mathrm{NH}_{3} \mathrm{PbI}_{3}$, Science 342, 344 (2013).

${ }^{4}$ A. Kojima, K. Teshima, Y. Shirai and T. Miyasaka, Organometal halide perovskites as visible-light sensitizers for photovoltaic cells, J. Am. Chem. Soc. 131, 6050 (2009).

${ }^{5} \mathrm{NREL}, \quad$ https://www.nrel.gov/pv/assets/images/efficiency-chart. png; (accessed January 16, 2018).

${ }^{6}$ H. S. Kim, C. R. Lee, J. H. Im, K. B. Lee, T. Moehl, A. Marchioro, S. J. Moon, R. Humphry-Baker, J. H. Yum, J. E. Moser, M. Gratzel and N. G. Park, Lead iodide perovskite sensitized all-solid-state submicron thin film mesoscopic solar cell with efficiency exceeding 9\%, Sci. Rep. 2, 1 (2012).

${ }^{7}$ W. Nie, H. Tsai, R. Asadpour, J.-C. Blancon, A. J. Neukirch, G. Gupta, J. J. Crochet, M. Chhowalla, S. Tretiak, M. A. Alam, H.-L. Wang and A. D. Mohite, High-efficiency solution-processed perovskite solar cells with millimeter-scale grains, Science 347, 522 (2015).

${ }^{8}$ H. P. Zhou, Q. Chen, G. Li, S. Luo, T. B. Song, H. S. Duan, Z. R. Hong, J. B. You, Y. S. Liu and Y. Yang, Interface engineering of highly efficient perovskite solar cells, Science 345, 542 (2014).

${ }^{9}$ B. Conings, L. Baeten, C. De Dobbelaere, J. D’Haen, J. Manca and H. G. Boyen, Perovskite-based hybrid solar cells exceeding $10 \%$ efficiency with high reproducibility using a thin film sandwich approach, Adv. Mater. 26, 2041 (2014).

${ }^{10}$ Y. Z. Wu, X. D. Yang, H. Chen, K. Zhang, C. J. Qin, J. Liu, W. Q. Peng, A. Islam, E. B. Bi, F. Ye, M. S. Yin, P. Zhang and L. Y. Han, Highly compact $\mathrm{TiO}_{2}$ layer for efficient hole-blocking in perovskite solar cells, Appl. Phys. Exp. 7, 052301-1 (2014).

${ }^{11}$ A. K. Chandiran, M. Abdi-Jalebi, A. Yella, M. I. Dar, C. Yi, S. A. Shivashankar, M. K. Nazeeruddin and M. Graetzel, Quantumconfined $\mathrm{ZnO}$ nanoshell photoanodes for mesoscopic solar cells, Nano Lett. 14, 1190 (2014).

${ }^{12}$ W. J. E. Beek, M. M. Wienk, M. Kemerink, X. N. Yang and R. A. J. Janssen, Hybrid zinc oxide conjugated polymer bulk heterojunction solar cells, J. Phys. Chem. B. 109, 9505 (2005).

${ }^{13}$ W. J. Ke, G. J. Fang, Q. Liu, L. B. Xiong, P. L. Qin, H. Tao, J. Wang, H. W. Lei, B. R. Li, J. W. Wan, G. Yang and Y. F. Yan, Low-temperature solution-processed tin oxide as an alternative electron transporting layer for efficient perovskite solar cells, $J$. Am. Chem. Soc. 137, 6730 (2015).

${ }^{14}$ C.-H. Chiang and C.-G. Wu, Bulk heterojunction perovskitePCBM solar cells with high fill factor, Nat. Photon. 10, 196 (2016).

${ }^{15}$ M. M. Lee, J. Teuscher, T. Miyasaka, T. N. Murakami and H. J. Snaith, Efficient hybrid solar cells based on meso-superstructured organometal halide perovskites, Science 338, 643 (2012).

${ }^{16}$ F. Zhang, X. C. Liu, C. Y. Yi, D. Q. Bi, J. S. Luo, S. R. Wang, X. G. Li, Y. Xiao, S. M. Zakeeruddin and M. Gratzel, Dopant-free donor (D)-D-D conjugated hole-transport materials for efficient and stable perovskite solar cells, Chemsuschem 9, 2578 (2016).

${ }^{17}$ J. Burschka, N. Pellet, S.-J. Moon, R. Humphry-Baker, P. Gao, M. K. Nazeeruddin and M. Graetzel, Sequential deposition as a route to high-performance perovskite-sensitized solar cells, Nature 499, 316 (2013).

${ }^{18}$ K. Zhu, N. Kopidakis, N. R. Neale, J. van de Lagemaat and A. J. Frank, Influence of surface area on charge transport and recombination in dye-sensitized $\mathrm{TiO}_{2}$ solar cells, J. Phys. Chem. B. 110, 25174 (2006). 
${ }^{19}$ A. Yella, L. P. Heiniger, P. Gao, M. K. Nazeeruddin and M. Gratzel, Nanocrystalline rutile electron extraction layer enables low-temperature solution processed perovskite photovoltaics with 13.7\% efficiency, Nano Lett. 14, 2591 (2014).

${ }^{20}$ Z. Liu, Q. Chen, Z. Hong, H. Zhou, X. Xu, N. De Marco, P. Sun, Z. Zhao, Y.-B. Cheng and Y. Yang, Low-temperature $\mathrm{TiO}_{x}$ compact layer for planar heterojunction perovskite solar cells, Acs Appl. Mater. Interf. 8, 11076 (2016).

${ }^{21}$ T. N. Murakami, T. Miyadera, T. Funaki, L. Cojocaru, S. Kazaoui, M. Chikamatsu and H. Segawa, Adjustment of conduction band edge of compact $\mathrm{TiO}_{2}$ layer in perovskite solar cells through $\mathrm{TiCl}_{4}$ treatment, ACS Appl. Mater. Interf. 9, 36708 (2017).

${ }^{22}$ P. Chen, X. T. Yin, M. D. Que, X. B. Liu and W. X. Que, Low temperature solution processed indium oxide thin films with reliable photoelectrochemical stability for efficient and stable planar perovskite solar cells, J. Mater. Chem. A. 5, 9641 (2017).

${ }^{23}$ M. I. Dar, N. Arora, P. Gao, S. Ahmad, M. Gratzel and M. K. Nazeeruddin, Investigation regarding the role of chloride in organic-inorganic halide perovskites obtained from chloride containing precursors, Nano Lett. 14, 6991 (2014).

${ }^{24}$ Y. Tidhar, E. Edri, H. Weissman, D. Zohar, G. Hodes, D. Cahen, B. Rybtchinski and S. Kirmayer, Crystallization of methyl ammonium lead halide perovskites: Implications for photovoltaic applications, J. Am. Chem. Soc. 136, 13249 (2014).

${ }^{25}$ P. M. Sommeling, B. C. O'Regan, R. R. Haswell, H. J. P. Smit, N. J. Bakker, J. J. T. Smits, J. M. Kroon and J. A. M. van Roosmalen, Influence of a $\mathrm{TiCl}_{4}$ post-treatment on nanocrystalline $\mathrm{TiO}_{2}$ films in dye-sensitized solar cells, J. Phys. Chem. B. 110, 19191 (2006).

${ }^{26}$ H. K. Adli, T. Harada, S. Nakanishi and S. Ikeda, Effects of $\mathrm{TiCl}_{4}$ treatment on the structural and electrochemical properties of a porous $\mathrm{TiO}_{2}$ layer in $\mathrm{CH}_{3} \mathrm{NH}_{3} \mathrm{PbI}_{3}$ perovskite solar cells, Phys. Chem. Chem. Phys. 19, 26898 (2017).

${ }^{27}$ M. Abdi-Jalebi, M. I. Dar, A. Sadhanala, S. P. Senanayak, F. Giordano, S. M. Zakeeruddin, M. Gratzel and R. H. Friend, Impact of a mesoporous titania-perovskite interface on the performance of hybrid organic-inorganic perovskite solar cells, J. Phys. Chem. Lett. 7, 3264 (2016).

${ }^{28}$ H.-S. Rao, B.-X. Chen, W.-G. Li, Y.-F. Xu, H.-Y. Chen, D.-B. Kuang and C.-Y. Su, Improving the extraction of photogenerated electrons with $\mathrm{SnO}_{2}$ nanocolloids for efficient planar perovskite solar cells, Adv. Funct. Mater. 25, 7200 (2015). 